\title{
Re-examining trophic dead ends: stable isotope values link gelatinous zooplankton to leatherback turtles in the California Current
}

\author{
Elizabeth D. Hetherington ${ }^{1,5, *}$, Carolyn M. Kurle ${ }^{1}$, Scott R. Benson ${ }^{2,3}$, T. Todd Jones ${ }^{4}$, \\ Jeffrey A. Seminoff ${ }^{2}$ \\ ${ }^{1}$ Division of Biological Sciences, University of California San Diego, La Jolla, California 92093, USA \\ ${ }^{2}$ Southwest Fisheries Science Center, National Marine Fisheries Service, National Oceanic and Atmospheric Administration, \\ La Jolla, California 92037, USA \\ ${ }^{3}$ Moss Landing Marine Laboratories, Moss Landing, California 95039, USA \\ ${ }^{4}$ Pacific Island Fisheries Science Center, National Marine Fisheries Service, National Oceanic and Atmospheric Administration, \\ Honolulu, Hawaii 96818, USA \\ ${ }^{5}$ Present address: Integrative Oceanography Division, Scripps Institution of Oceanography, University of California San Diego, \\ La Jolla, California 92037, USA
}

\begin{abstract}
Predator-prey interactions provide essential information for tracing energy flow through food webs and evaluating the structure and function of ecosystems. In pelagic environments, these interactions are often difficult to discern, which is problematic for identifying specific energy pathways that support populations of protected species. We examined the trophic ecology of an endangered population of leatherback turtles Dermochelys coriacea and their gelatinous prey in the California Current-Large Marine Ecosystem (CC-LME). We combined carbon and nitrogen bulk stable isotope analysis and compound-specific isotope analysis of amino acids (CSIA-AA) with Bayesian statistical approaches to examine the diets of leatherbacks and their prey (scyphozoans and thaliaceans) sampled in the CC-LME. Our objectives were to evaluate (1) temporal changes in leatherback trophic position, (2) the contribution of different gelatinous prey to leatherback diets, and (3) trophic structure of the leatherback food web by estimating trophic positions and isotopic niches of leatherbacks and their potential prey. Leatherback trophic positions did not change over time, although carbon isotope values suggest a temporary shift in leatherback habitat in 2005, coincident with anomalous upwelling conditions. Bayesian mixing models suggest that carnivorous sea nettles Chrysaora fuscescens were the largest contributor to leatherback diet, followed by filter-feeding thaliaceans. Isotope analyses provided useful and ecologically realistic estimates of trophic structure, where trophic positions were lowest for thaliaceans, intermediate for scyphozoans, and highest for leatherbacks. Overall, our findings provide information on leatherback foraging ecology over a $13 \mathrm{yr}$ period and the trophic structure of gelatinous zooplankton that support the leatherback population in the CC-LME.
\end{abstract}

KEY WORDS: Foraging ecology $\cdot$ Food web $\cdot$ Leatherback turtle $\cdot$ Gelatinous zooplankton $\cdot$ Trophic position $\cdot$ Stable isotope analysis

\section{INTRODUCTION}

Predator-prey interactions are the foundations of food web architecture, providing fundamental information on how energy flows through ecosystems

\footnotetext{
${ }^{*}$ Corresponding author: ehetheri@ucsd.edu
}

(Paine 1980, Polis \& Strong 1996). Within food webs, top predators can perform critical functions, such as regulating populations of prey through top-down processes (Estes \& Duggins 1995, Pace et al. 1999, Baum \& Worm 2009). However, many populations of

(C) Elizabeth D. Hetherington, Carolyn M. Kurle and, outside the USA, The U.S. Government 2019. Open Access under Creative Commons by Attribution Licence. Use, distribution and reproduction are unrestricted. Authors and original publication must be credited. Publisher: Inter-Research · www.int-res.com 
predators are facing declines and unprecedented challenges due to an array of anthropogenic pressures (e.g. commercial fisheries, plastic pollution, contaminants, and climate change) and are of great conservation concern (Myers \& Worm 2003, Sibert et al. 2006, Wallace et al. 2011, Davidson et al. 2012, Hazen et al. 2013). To manage these species, we first must identify the energy pathways and distinct prey resources that support their populations and are critical to their survival. In pelagic ecosystems, predatorprey (i.e. trophic) interactions are often difficult to directly observe, which leads to significant gaps in our comprehension of food web structure and the trophic pathways that support predator populations.

Our study focuses on the leatherback sea turtle Dermochelys coriacea, an endangered and highly migratory gelativore consumer. Leatherbacks spend the majority of their lives in inaccessible pelagic habitats (Hays et al. 2004, Bailey et al. 2012), although some individuals use coastal habitats for extended periods of time for foraging or breeding (James et al. 2005, 2006, Dodge et al. 2014, Robinson et al. 2016, Aleksa 2017). Examining leatherback diet is essential for understanding their foraging ecology and how they meet the energetic threshold required for reproduction. Leatherbacks meet their energetic demands by consuming from 65 to $117 \mathrm{~kg} \mathrm{~d}^{-1}$ (Jones et al. 2012) of gelatinous zooplankton (Starbird et al. 1993, Benson et al. 2007a, Fossette et al. 2010, Dodge et al. 2011, Heaslip et al. 2012), including scyphozoan jellies and thaliaceans (i.e. salps and pyrosomes; Fig. 1). However, the degree to which leatherbacks consume and select for different gelatinous prey remains somewhat unknown, particularly for certain leatherback populations (e.g. western Pacific) and life history stages (i.e. offshore; Fossette et al. 2012, Heaslip et al. 2012.)

Examining leatherback diets presents several challenges, as gelatinous zooplankton are understudied compared to other mid-trophic level taxa. This limitation can partially be attributed to the difficulties associated with the collection of fragile gelatinous taxa that are easily destroyed by common sampling techniques (e.g. net tows). Additionally, they are quickly digested and difficult to identify in the stomach contents of predators. Furthermore, gelatinous zooplankton have been traditionally ignored in food web studies, viewed as non-important ecosystem members and 'trophic dead ends' that do not transfer energy to many higher trophic level species (Francis et al. 2012, Ruzicka et al. 2012, Hays et al. 2018). This paradigm is changing, as recent studies have illustrated the important contributions of gelatinous zooplankton to food web dynamics and highlight major gaps in our under- standing of the ecological niches of gelatinous zooplankton (Henschke et al. 2016, Pascual et al. 2016).

Because leatherbacks are widely distributed throughout the global ocean and specialize in feeding on gelatinous taxa, understanding their predator-prey relationships provides insight into a poorly resolved component of marine food webs. The distinct energy pathways that support leatherback populations vary depending on the types of gelatinous prey they consume. This is important because energy is lost with each trophic transfer in a food web and the number of transfers affects the amount of energy available to support predator populations (Polis 1991, Post 2002, Barnes et al. 2010). Thus, examining the contributions of different gelatinous taxa, which may have different trophic positions, to leatherback diets is necessary for understanding carbon flow through this portion of the food web.

Specifically, our study focuses on the foraging ecology of leatherbacks and their gelatinous prey in the California Current-Large Marine Ecosystem (CCLME). This region is a productive eastern boundary upwelling system and an important leatherback foraging area for a subgroup of the western Pacific metapopulation, which is critically endangered and in a state of decline (Dutton et al. 2007, Benson et al. 2011, Seminoff et al. 2012). The CC-LME is a highly dynamic region which experiences considerable variability in environmental parameters on seasonal, interannual, decadal, and multidecadal time scales (Lynn

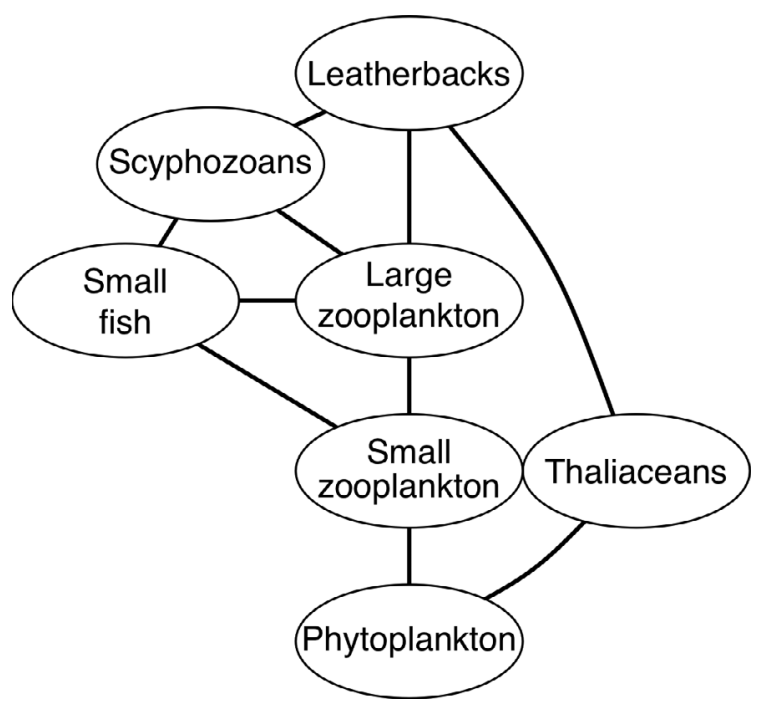

Fig. 1. Conceptual diagram of 2 potential gelatinous food web pathways in the California Current-Large Marine Ecosystem (CC-LME) that support endangered leatherback turtles, where lines indicate trophic interactions (predatorprey relationships) 
\& Simpson 1987, Bograd \& Lynn 2003, Jacox et al. 2016). In addition, the CC-LME has recently experienced an unprecedented marine heatwave (Di Lorenzo \& Mantua 2016), a strong El Niño event (Jacox et al. 2016), and gelatinous zooplankton (salp and pyrosome) blooms and range expansions (Smith et al. 2014, Sutherland et al. 2018).

Variability in oceanographic conditions in the CCLME can influence the abundances and distribution of phytoplankton and zooplankton, which has the potential to affect leatherback foraging. Previous research (Saba et al. 2008, Wallace \& Saba 2009) has suggested that differences in oceanic conditions, specifically, decreases in primary production caused by periodic El Niño events, may limit prey availability and reproductive output of leatherbacks in the eastern Pacific (Wallace et al. 2006, Saba et al. 2008, Wallace \& Saba 2009). Examining leatherback diet and prey selectivity over time may provide insight into how environmental variability influences leatherback foraging ecology in the CC-LME, which is useful for predicting changes to these energy pathways under future anthropogenic stressors or changes in oceanographic conditions.

For a time-integrated approach to understanding diet, we use bulk and compound-specific stable isotope analyses. Bulk nitrogen isotope ratios $\left(\delta^{15} N\right)$ from marine organisms have been used extensively as a complementary tool (compared to stomach contents analysis and animal-borne camera videos) for elucidating animal diets and estimating trophic position (TP), whereas carbon isotope ratios $\left(\delta^{13} \mathrm{C}\right)$ have been used to delineate carbon-based sources of production in food webs (DeNiro \& Epstein 1981, Hobson 1999, Fry 2006). Estimating TPs of consumers from bulk $\delta^{15} \mathrm{~N}$ values and interpreting spatial or temporal patterns in $\delta^{15} \mathrm{~N}$ values requires a measurement of baseline (i.e. phytoplankton) $\delta^{15} \mathrm{~N}$ values. These values vary in marine ecosystems, as they are governed by the dominant nitrogen transformation or cycling processes in the region (i.e. nitrogen recycling, $\mathrm{N}_{2}$ fixation, or denitrification (Cline \& Kaplan 1975, Altabet 2001, Voss et al. 2001, Montoya et al. 2002, Hannides et al. 2009). To account for the baseline variability in $\delta^{15} \mathrm{~N}$ values, we use compound-specific isotope analysis of amino acids (CSIA-AA), which provides a proxy measurement of baseline $\delta^{15} \mathrm{~N}$ values (see Section 2 for more details). The $\delta^{15} \mathrm{~N}$ values of amino acids can therefore be used to estimate TPs of consumers while accounting for variability in baseline $\delta^{15} \mathrm{~N}$ values (Popp et al. 2007, Chikaraishi et al. 2009). The CSIA-AA approach for estimating TPs has become increasingly used in ecology (Ohkouchi et al.
2017). Notably, recent studies highlight the utility of CSIA-AA for examining the diets of marine turtle populations whose prey are difficult to identify via stomach contents analysis (Vander Zanden et al. 2013, Arthur et al. 2014, Peavey et al. 2017, Hetherington et al. 2018).

Many studies on leatherbacks are limited to nesting beaches when turtles are more easily accessible. Here, we used samples collected from leatherbacks at a neretic north-eastern Pacific foraging area, which presents an opportunity to examine habitat use and foraging ecology from a different life history phase. The primary objectives of this study are to examine the trophic structure and ecological niches of gelatinous zooplankton that support a leatherback foraging population, determine the contribution of these species to leatherback diets, and evaluate potential changes in leatherback trophic ecology over a 13 yr period. For a robust estimate of trophic structure, we use multiple approaches for estimating TP and compare the strengths and limitation of these different techniques.

\section{MATERIALS AND METHODS}

\subsection{Sample collection and isotope analyses}

We collected leatherback Dermochelys coriacea skin samples for 7 yr over a 13-yr period. Leatherback sampling locations and dates (August to October of 2003-2016) were based on knowledge of occurrence of foraging leatherback turtles from previous aerial surveys (Benson et al. 2007b). Capture and sampling activities for leatherbacks and gelatinous zooplankton (salps; Class Thaliacea) and the scyphozoans Chrysaora fuscenscens (sea nettles), Chrysaora fuscenscens (sea nettles), Chrysaora colorata (sea nettles), Phacellophora camtschatica (egg-yolk jellies), and Aurelia spp. (moon jellies) occurred in neritic waters $(<100 \mathrm{~m}$ depth) between Monterey Bay and San Francisco, California, USA (approximately $36.65^{\circ}$ to $37.80^{\circ} \mathrm{N}$; $121.85^{\circ}$ to $122.95^{\circ} \mathrm{W}$ ). We located leatherbacks with the aid of a spotter aircraft and captured individuals with a break-away hoop net from a 9-m aluminum Munson vessel featuring a retractable bow that facilitated boarding the captured turtles. We obtained a skin sample $(<5 \mathrm{~mm}$ diameter, $\sim 1 \mathrm{~mm}$ deep) from each captured turtle $(\mathrm{n}=40$; see Table $\mathrm{S} 1$ in the Supplement at www.int-res.com/articles/suppl/m632p205 _supp.pdf) using forceps and a new razor blade for each sample. We sampled the epidermis layer at the margin of the carapace and the rear flipper. Stable 
isotope values from leatherback skin are integrated over several months, likely on the order of 4 to 6 mo for adults (Seminoff et al. 2007, 2009, Reich et al. 2008). For gelatinous zooplankton, we captured whole organisms at or near the surface on an opportunistic basis, when they were in close proximity to leatherbacks. These samples were collected using a scoop net. In the field, we initially stored gelatinous zooplankton and leatherback samples on ice and/or in a saturated salt solution. In the laboratory, we stored all samples for several months at $-80^{\circ} \mathrm{C}$ until further analysis.

To prepare leatherback and gelatinous zooplankton samples for isotope analysis, we gently rinsed samples with deionized water, lyophilized, homogenized, and weighed them in tin capsules. Bulk isotope analysis was performed at the University of Florida using a Costech ecS 4010 elemental combustion system interfaced via a ConFlo III device (Finnigan MAT) to a Deltaplus gas isotope-ratio mass spectrometer (Finnigan MAT). Stable isotope ratios are expressed in standard delta $(\delta)$ notation in parts per thousand (\%). Stable isotope values were measured against laboratory standards: ${ }^{13} \mathrm{C}$ was Baker Acetanilide calibrated monthly against the Peedee Belemnite (PDB) limestone formation international standard. The $\mathrm{R}_{\text {standard }}$ for ${ }^{15} \mathrm{~N}$ was IAEA N1 Ammonium Sulfate calibrated monthly against atmospheric $\mathrm{N}_{2}$ and USGS Nitrogen standards. We analyzed standard materials every 6 to 7 samples to ensure analytical precision.

We analyzed a small subset of gelatinous zooplankton samples selected for CSIA-AA at the University of Hawaii's Stable Isotope Biogeochemistry Laboratories. Amino acid isotope values from leatherbacks were previously published (Seminoff et al. 2012) and were from individuals that were classified as California Current/eastern Pacific foragers. These samples were analyzed at the same facility, using the same protocol as the gelatinous zooplankton we analyzed for this study. Samples were hydrolyzed (6 N $\mathrm{HCl}, 150^{\circ} \mathrm{C}$ for $70 \mathrm{~min}$ ), esterified (4:1 isopropanol: acetyl chloride), derivatized (3:1 methylene chloride: trifluoroacetyl anhydride), and analyzed using a Trace GC gas chromatograph and a Thermo Delta XP mass spectrometer through a GC-C III combustion furnace $\left(980^{\circ} \mathrm{C}\right)$, reduction furnace $\left(680^{\circ} \mathrm{C}\right)$, and a liquid nitrogen cold trap. Samples were injected (split/splitless, 5:1 split ratio) with a $180^{\circ} \mathrm{C}$ injector temperature and

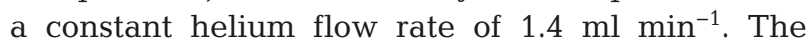
CSIA-AA samples were analyzed in triplicate, where values were corrected to the $\delta^{15} \mathrm{~N}$ values of internal reference compounds. See Popp et al. (2007) or Han- nides et al. (2013) for more details on CSIA-AA sample preparation and analysis.

\subsection{Environmental data}

Leatherback habitat use and diet are likely influenced by environmental parameters, so we were interested in examining the relationships between environmental data and isotope ratios. To infer upwelling intensity, we used a mean, monthly index, generated from NOAA's Environmental Research Division (www. pfeg.noaa.gov). This proxy for upwelling intensity denotes the wind strength forcing on the ocean, which is measured in metric tons per second per $100 \mathrm{~m}$ of coastline. These units therefore represent the mean amount of water that is upwelled through the bottom of the Ekman layer each second, along a defined region of coastline. Data were available for 26 positions in the northeastern Pacific, and we used data from $36^{\circ} \mathrm{N}$, $119^{\circ} \mathrm{W}$, as it is closest to our sampling locations and known habitat for leatherbacks. Upwelling data were used to create time series. Given the strong seasonality in the CC-LME, we used the decompose function in $\mathrm{R}$ ( $\mathrm{R}$ Core Team 2016) to break the time series into seasonal, trend and irregular components using moving averages. We then removed the seasonal component and tested for outliers (using the package 'tsoutliers'; https://cran.r-project.org/web/packages/tsoutliers/) to identify potentially anomalous upwelling conditions during our sampling period.

We obtained abundances (number per $\mathrm{m}^{2}$ ) of thaliaceans (salps and pyrosomes) from spring (April) sampling efforts from the California Cooperative Oceanic Fisheries Investigations (CalCOFI) and the Scripps Institution of Oceanography's open-access Zooplankton Database (https://oceaninformatics.ucsd. edu/zooplankton/). Abundance estimates were available from 2003-2013 and represent the 'Central California' region of the CalCOFI sampling grid, which encompasses Lines 60 to 70 and stations out to and including 90. Zooplankton samples were collected using bongo tows (see calcofi.org for details on sample collection). Samples from multiple bongo tows were pooled within a region to obtain estimates of spring abundance for certain taxa. We used these pooled estimates to evaluate thaliacean abundances over time, which is relevant for interpreting trends in leatherback diet and habitat use. Because turnover rates for turtle skin are $\sim 3$ to 4 mo (Seminoff et al. 2009), our leatherback isotope values are reflective of foraging at the end of spring, rather than the time of their collection in the summer. 


\subsection{Data analyses}

All statistical analyses were conducted using the software R (R Core Team 2016), where $\mathrm{p}<0.05$ was used to define statistical significance. We used Q-Q plots and Shapiro-Wilks tests to determine that our bulk isotope data were normally distributed. We used raw isotope data for analyses and did not transform data. To test for potential temporal changes in leatherback diet or habitat use, we used univariate linear models to evaluate changes in $\delta^{13} \mathrm{C}$ and $\delta^{15} \mathrm{~N}$ from 2003 to 2016 . We also tested for differences in both isotope values and size (curved carapace length [CCL]) between male and female leatherbacks using Welch's 2 sample $t$-tests.

Prior to estimating the contributions of different gelatinous prey to leatherback diets, we used an ANOVA and Tukey's post hoc analysis to evaluate whether prey and baseline isotope values were distinct from one another and from leatherbacks. Then, to evaluate the contributions of these potential prey to leatherback diet, we used the package SIMMR (Stable Isotope Mixing Models in R), which relies on a Bayesian framework to solve mixing equations with stable isotope data (Parnell et al. 2013). The functions in this package were used to run Markov Chain Monte Carlo simulations (see the Supplement for details) to repeatedly estimate the proportions of different prey items in leatherback diets. From 10000 simulations, we estimated the proportions of gelatinous prey to leatherback diet. We then sampled those iterations to calculate the probability distributions of the following prey groups to leatherback diets: Thaliacea (salps), sea nettles Chrysaora fuscenscens, egg-yolk jellies Phacellophora camtschatica, and moon jellies Aurelia spp., which are hereafter referred to by their class (Thaliacea) or genera (Chrysaora, Phacellophora, or Aurelia). Due to the small sample size $(\mathrm{n}=4)$, we did not include Chrysaora colorata in any statistical analyses, including the stable isotope mixing model.

Stable isotope mixing models are useful for determining contributions of different prey but also have inherent limitations. While the gelatinous taxa we selected may not represent a comprehensive list of potential leatherback prey, they are representative of the major groups of prey organisms that leatherbacks are known to target. Although we were unable to sample pyrosomes, which leatherbacks do consume, pyrosomes are filter-feeding thaliaceans, like salps. Thus, we used salps as a proxy for all thaliaceans. Due to the difficulties associated with sampling foraging leatherbacks and their prey, our sample size per year was limited, and there were some years in which no samples were collected. For this reason, we were unable to run the mixing model for different years and pooled samples from all years for the mixing model.

Stable isotope values can also provide information about animal resource use and therefore may provide insight into their ecological niche space (Newsome et al. 2007, Jackson et al. 2011, Rossman et al. 2016). We compared the isotopic niche widths of leatherbacks and gelatinous zooplankton, using the package SIBER (Stable Isotope Bayesian Ellipses in R) in R (R Core Team 2016). Using SIBER functions, we calculated the isotopic ranges for each species or group. The univariate $\delta^{13} \mathrm{C}$ and $\delta^{15} \mathrm{~N}$ ranges were used to calculate bivariate ellipses (Jackson et al. 2011), known as a standard ellipse area (SEA), which are corrected for sample size and represent the isotopic niche width of an organism. Calculating an SEA is advantageous over other metrics (e.g. calculating convex hulls) because it captures the majority of the data but is not skewed by extreme values (see Jackson et al. 2011 for detailed methodology on SIBER metrics and functions). Within SIBER, we used a Bayesian approach to estimate SEA (SEA-B). This approach provided a metric by which to measure uncertainty (i.e. credible intervals) around our SEA-B estimates, which is particularly useful given our small sample sizes for some gelatinous taxa. To test for differences in isotopic niches among taxa, we used a maximum likelihood approach to compare pairs of Markov Chain Monte Carlo simulations of SEA-B posterior distributions from different taxa.

\subsection{Estimating trophic positions (TPs)}

Estimating TPs of species allows for the trophic placement of organisms within a food web model. However, TP estimates derived from different approaches can produce conflicting results. We estimated TPs of leatherbacks and gelatinous organisms using multiple approaches, which rely on either bulk or amino acid isotope values. First, we used bulk $\delta^{15} \mathrm{~N}$ values to estimate TPs of species using a novel Bayesian approach in the package 'tRophicposition' in R (Quezada-Romegialli et al. 2018; see the Supplement).

The advantages of this Bayesian approach were that we could include variability in 2 key parameters that are used to estimate $\mathrm{TP}_{\text {bulk }}$ : the baseline isotope values of primary producers and the trophic discrimination factor (TDF). Thus, our TP estimates are likely 
more robust than relying on traditional approaches for estimating $\mathrm{TP}_{\text {bulk }}$. $\mathrm{TP}_{\text {bulk }}$ was calculated using the following equation:

$$
\delta^{15} \mathrm{~N}_{\text {consumer }}=\delta^{15} \mathrm{~N}_{\text {baseline }}+\operatorname{TDF}\left(\mathrm{TP}_{\text {bulk }}-\lambda\right)
$$

where $\lambda$ represents the TP of the baseline isotope data. We used a range of baseline $\delta^{15} \mathrm{~N}$ values, from particulate organic matter in the California Current from Kurle \& McWhorter (2017).

Particulate organic matter consists of organisms other than primary producers (Lorrain et al. 2015), and therefore, we set $\lambda=1.5$. The TDF values were set to $2.9 \pm 0.32$ standard error (McCutchan et al. 2003). See the Supplement for more details.

The second approach that we used to estimate TP was CSIA-AA $\left(\mathrm{TP}_{\text {CSIA }}\right)$, which relies on amino acid $\delta^{15} \mathrm{~N}$ values. The sample size for all taxa was limited due to the high cost and labor associated with this analysis. We used the following equation from Chikaraishi et al. (2009) to estimate TPs of 3 scyphozoan taxa (Chrysaora fuscescens, Phacellophora camtschatica, and Aurelia spp.):

$$
\mathrm{TP}_{\text {CSIA }}=\frac{\left(\delta^{15} \mathrm{~N}_{\text {trophic }}-\delta^{15} \mathrm{~N}_{\text {source }}\right)-\beta}{\mathrm{TDF}}+1
$$

where $\mathrm{TP}_{\mathrm{CSIA}}$ is the TP based on the difference in mean $\delta^{15} \mathrm{~N}$ values from the trophic (glutamic acid) and source (phenylalanine) amino acids, TDF is $7.6 \%$ (Chikaraishi et al. 2009) and represents the ${ }^{15} \mathrm{~N}$ enrichment of trophic relative to source amino acids per trophic step, and $\beta$ represents $\delta^{15} \mathrm{~N}_{\text {trophic }}-\delta^{15} \mathrm{~N}_{\text {source }}$ in primary producers (3.4\%o; Chikaraishi et al. 2009).

To compare amino acid-derived TP estimates between leatherbacks and their prey, we used published $\delta^{15} \mathrm{~N}$ amino acid data and TP estimates from Seminoff et al. (2012). These individual leatherbacks were sampled on their western Pacific nesting beaches but were classified as California Current foragers. These turtles likely migrated from the California Current, and we therefore used their isotope values as a proxy for leatherbacks foraging in the CC-LME. Eq. (2) was also used to estimate TP by Seminoff et al. (2012), which facilitated a comparison to our gelatinous zooplankton samples.

Because our sample size for CSIA-AA was limited, we could not test for statistical differences between $\mathrm{TP}_{\text {CSIA }}$ estimates. Rather, we used bulk isotope values to compare $\mathrm{TP}_{\text {bulk }}$ among groups. We were unable to use more recently developed equations for estimating $\mathrm{TP}_{\mathrm{CSIA}}$ (e.g. Bradley et al. 2015, Nielsen et al. 2015), as these approaches rely on amino acids other than phenylalanine or glutamic acid, which were not detected on chromatograms in our analyses.

\section{RESULTS}

\subsection{Leatherback isotope values}

The $\delta^{15} \mathrm{~N}$ and $\delta^{13} \mathrm{C}$ values from leatherback Dermochelys coriacea skin were unimodally distributed (Fig. S1 in the Supplement). This trend was evident when all samples were grouped together and when samples from males and females were analyzed separately. We found no significant trend in leatherback $\delta^{15} \mathrm{~N}$ values over time $\left(F_{1,51}=1.0, \mathrm{R}^{2}=0.001, \mathrm{p}=0.30\right)$. However, there was a weak significant difference in $\delta^{13} \mathrm{C}$ values $\left(F_{1,51}=4.95, \mathrm{R}^{2}=0.07, \mathrm{p}=0.03\right.$; Fig. $\left.2 \mathrm{a}, \mathrm{b}\right)$. A Tukey's post hoc test indicated that this difference was driven by high $\delta^{13} \mathrm{C}$ values in 2005. Leatherback $\delta^{13} \mathrm{C}$ values in 2005 were higher than in $2003(\mathrm{p}=$ $0.01), 2004(\mathrm{p}<0.001), 2007$ ( $\mathrm{p}=<0.001)$, and 2016 $(\mathrm{p}<0.0001)$. The $\delta^{15} \mathrm{~N}$ values were positively related to leatherback size, measured by curved carapace length $\left(F_{1,36}=13.02, \mathrm{R}^{2}=0.24, \mathrm{p}<0.001\right)$, but we found no relationship between $\delta^{13} \mathrm{C}$ values and curved carapace length $\left(F_{1,36}=0.11, \mathrm{R}^{2}=-0.24, \mathrm{p}>0.1\right.$; Fig. 2c,d).

Leatherback isotope ratios are representative of both males $(n=10)$ and females $(n=30)$. Female turtles were larger than males $\left(t_{43.6}=3.06, \mathrm{p}<0.01\right)$, where means \pm SD for females and males were 158.9 $\pm 7.7 \mathrm{~cm}$ and $154.1 \pm 5.1 \mathrm{~cm}$, respectively. The turtles sampled in this study were adults, as the CCL at maturation for Pacific leatherbacks is 145 to $160 \mathrm{~cm}$ (Saba et al. 2008). However, there were no differences in isotope values between male and female leatherback turtles $\left(\delta^{15} \mathrm{~N}: t_{37.3}=1.29, \mathrm{p}=0.20 ; \delta^{13} \mathrm{C}: t_{34.9}=-0.38\right.$, $\mathrm{p}=0.70$; Fig. S2 in the Supplement). The mean $\delta^{15} \mathrm{~N}$ and $\delta^{13} \mathrm{C}$ values for females were $13.6 \pm 1.0 \%$ and $-16.2 \pm 0.8 \%$, respectively, and for males were $13.2 \pm$ $0.8 \%$ and $-16.1 \pm 0.8 \%$, respectively.

\subsection{Trophic structure and food web analyses}

Sample sizes of leatherbacks and putative prey species collected for stable isotope analyses varied across taxa, as did their $\delta^{15} \mathrm{~N}$ and $\delta^{13} \mathrm{C}$ values (Table 1 ). We found significant differences in $\delta^{15} \mathrm{~N}$ values among gelatinous zooplankton and leatherback turtles $\left(F_{5,286}=198.1, \mathrm{R}^{2}=0.77, \mathrm{p}<0.00001\right)$. A Tukey's pairwise comparison indicated that 12 of 15 comparisons were significantly different $(\mathrm{p}<0.05$; Table S2 in the Supplement). There were no significant differences ( $\mathrm{p}>0.05)$ in $\delta^{15} \mathrm{~N}$ values between Chrysaora and Aurelia or between Phacellophora and Aurelia. $\delta^{13} \mathrm{C}$ values were also significantly different among 
Fig. 2. Relationships between stable isotope values from leatherback skin samples $(\mathrm{n}=40)$ over $(\mathrm{A}, \mathrm{C})$ time and $(B, D)$ leatherback size: (A) $\delta^{15} \mathrm{~N}\left(\mathrm{R}^{2}=0.001, \mathrm{p}=0.30\right)$, (B) $\delta^{15} \mathrm{~N}\left(\mathrm{R}^{2}=0.24, \mathrm{p}<0.001\right)$, (C) $\delta^{13} \mathrm{C}\left(\mathrm{R}^{2}=0.07, \mathrm{p}=0.03\right)$ and (D) $\delta^{13} \mathrm{C}\left(\mathrm{R}^{2}=-0.24, \mathrm{p}>\right.$ 0.1 ). Size was measured by curved carapace length
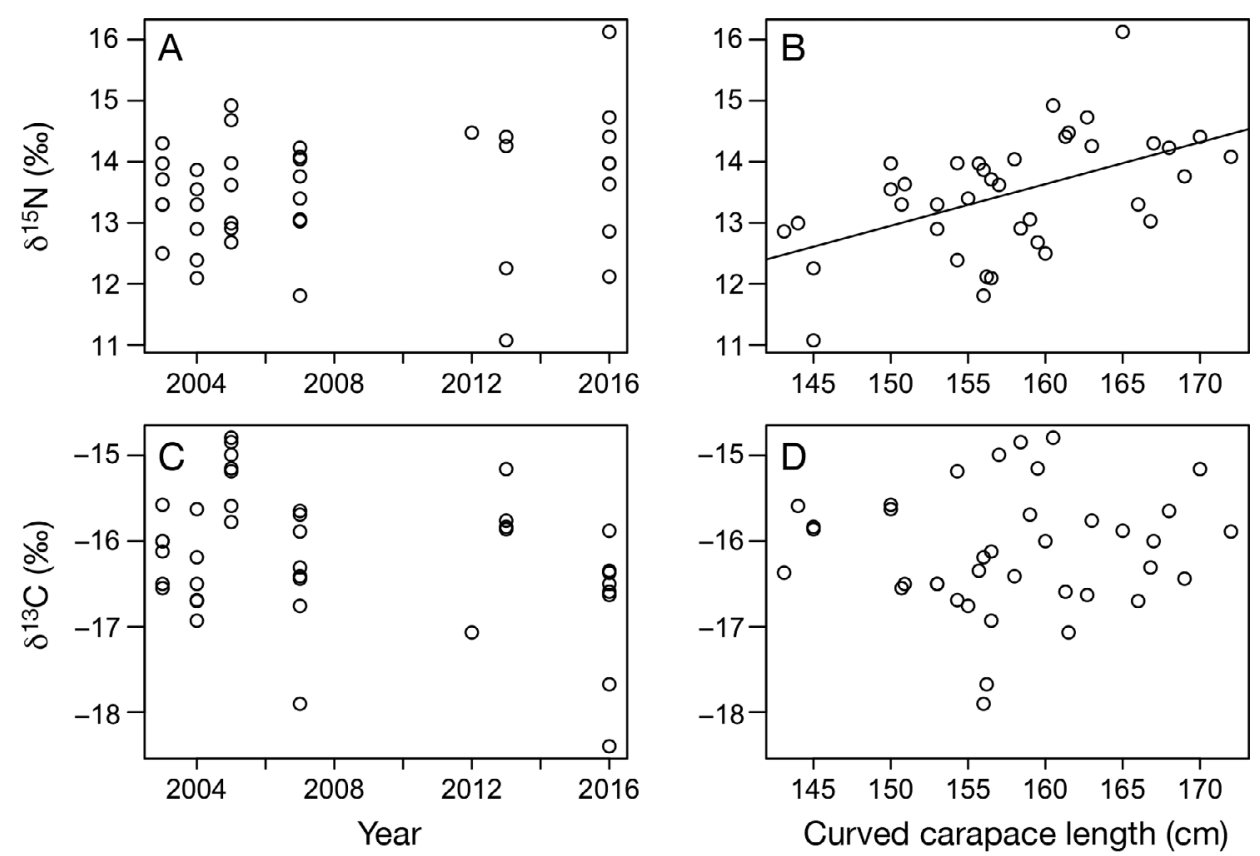

species $\left(F_{5,286}=175.4, \mathrm{R}^{2}=0.75, \mathrm{p}<0.00001\right.$; Fig. 3A $)$, but Tukey's pairwise comparisons indicated significant differences $(\mathrm{p}<0.05)$ only between thaliaceans and leatherback tissues (see Table S2).

We used an isotope mixing model approach for estimating the contributions of different gelatinous organisms to leatherback diets. Based on the SIMMR model, leatherbacks in the CC-LME primarily forage on Chrysaora and thaliaceans (Fig. 4, Table 2). We found the highest probability (0.59) for the following order of prey, from largest to smallest contributors of leatherback diet: Chrysaora, thaliaceans, Aurelia, Phacellophora. The second highest probability was 0.30 for the following order: Chrysaora, thaliaceans, Phacellophora, and Aurelia. The median posterior estimates for the relative contribution of prey items were: Chrysaora (72\%), thaliaceans (18\%), Aurelia (5\%), and Phacellophora (3\%; Table 2).

Table 1. Sample sizes and means (standard deviations) of $\delta^{15} \mathrm{~N}$ and $\delta^{13} \mathrm{C}$ values (\%) from leatherback turtle Dermochelys coriacea and gelatinous zooplankton tissues that were analyzed in this study

\begin{tabular}{|lccc|}
\hline Taxa & $\mathrm{N}$ & $\delta^{15} \mathrm{~N}$ & $\delta^{13} \mathrm{C}$ \\
\hline Dermochelys coriacea & 40 & $13.5(0.9)$ & $-16.2(0.8)$ \\
Phacellophora spp. & 15 & $12.7(0.8)$ & $-17.4(1.2)$ \\
Chrysaora colorata & 4 & $12.3(1.1)$ & $-16.6(1.5)$ \\
Chrysaora fuscescens & 27 & $10.7(0.6)$ & $-16.9(0.7)$ \\
Aurelia spp. & 14 & $11.5(0.4)$ & $-17.4(0.6)$ \\
Thaliacea & 11 & $9.2(0.3)$ & $-18.4(0.9)$ \\
\hline
\end{tabular}

To estimate the isotopic niche widths of species, we calculated the standard ellipse areas using a Bayesian approach (SEA-B). Isotopic niche widths varied among taxa (Fig. 3; Table S3 in the Supplement). The median SEA-B values for leatherback and prey were, in order from smallest to largest area: Aurelia $\left(0.50 \%{ }^{2}\right)$, thaliaceans $\left(0.91 \%{ }^{2}\right)$, Chrysaora $\left(1.62 \%{ }^{2}\right)$, and Phacellophora $\left(1.79 \%^{2}\right)$, and leatherbacks $\left(1.80 \%^{2}\right)$.

\subsection{Trophic position estimates}

Using bulk $\delta^{15} \mathrm{~N}$ data and a Bayesian approach, median posterior $\mathrm{TP}_{\text {bulk }}$ values were in the following order, from highest to lowest; leatherbacks (3.1), Phacellophora (2.9), Aurelia (2.5), Chrysaora (2.3), and thaliaceans (1.9; Fig. 5, Table 3). Pairwise comparisons showed that there was a high probability (>95\%) that leatherback TPs were higher than all prey items, and thaliacean $\mathrm{TP}_{\text {bulk }}$ estimates were lower than all other species (>99.9\%). Among the scyphozoans, the $\mathrm{TP}_{\text {bulk }}$ estimate for Chrysaora was less than those for Aurelia and Phacellophora, which had the highest $\mathrm{TP}_{\text {bulk }}$ of all gelatinous zooplankton (Table S4 in the Supplement).

We also used the $\delta^{15} \mathrm{~N}$ values from amino acids to estimate TP $\left(\mathrm{TP}_{\mathrm{CSIA}}\right)$, although the small sample size limited our ability to statistically test for differences in TPs among species. The gelatinous prey $\mathrm{TP}_{\mathrm{CSIA}}$ values were similar among taxa, where $\mathrm{TP}_{\text {CSIA }}$ for 

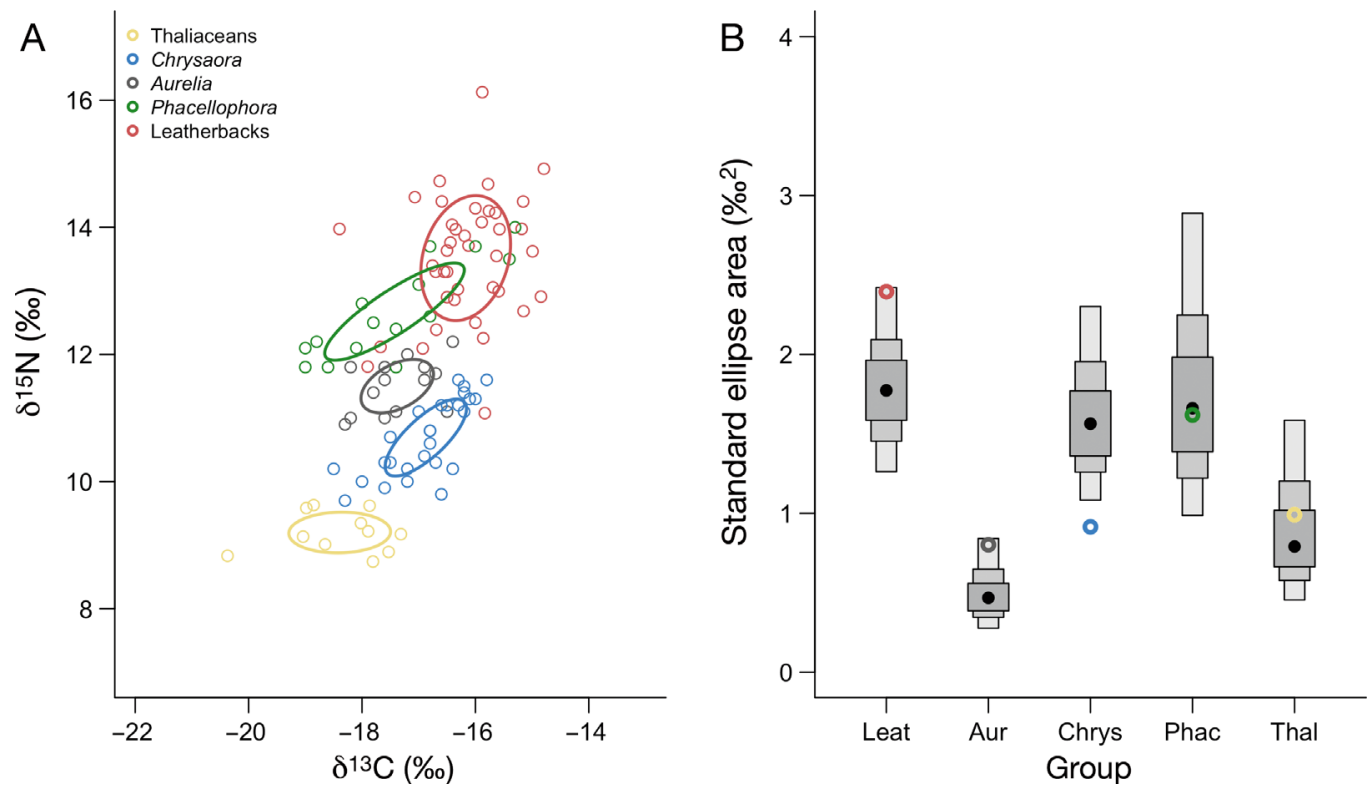

Fig. 3. (A) The $\delta^{15} \mathrm{~N}$ and $\delta^{13} \mathrm{C}$ values of thaliaceans $(\mathrm{n}=11)$, Chrysaora $(\mathrm{n}=27)$, Aurelia $(\mathrm{n}=15)$, Phacellophora $(\mathrm{n}=15)$, and leatherbacks $(\mathrm{n}=40)$, where isotope values are uncorrected for trophic discrimination factors. Ellipses represent the Standard Ellipse Areas (SEA), corrected for sample size, which were calculated using a maximum likelihood approach in the R package 'SIBER.' (B) Bayesian SEA (SEA-B) estimates for leatherbacks (Leat) and gelatinous zooplankton (Thal: thaliaceans, Aur: Aurelia, Chrys: Chrysaora, Phac: Phacellophora), where black circles represent the mean SEA-B values, and grey boxes represent the 50,75, and $95 \%$ credible intervals. The open, colored circles represent the SEA values that were calculated based on a maximum likelihood approach (and corrected for sample size) corresponding to Fig. 3A

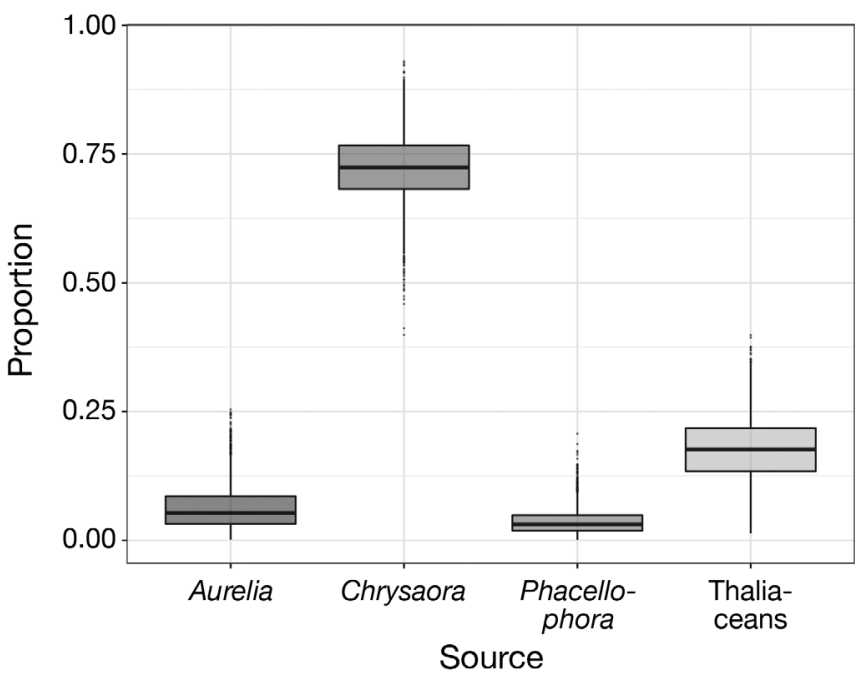

Fig. 4. Estimates of the relative contributions (proportions) of 4 gelatinous prey groups to the diets of leatherbacks in the California Current-Large Marine Ecosystem. Estimates were derived using an isotope mixing model built in the $\mathrm{R}$ package 'SIMMR' using 10000 Markov Chain Monte Carlo simulations. Black lines represents the median and grey boxes are first $(25$ th $\%)$ and third $(75 \%)$ quartiles. Error bars indicate credible intervals, the outer edges of which are $97.5 \%$

Phacellophora were 2.9 and $2.9(\mathrm{n}=2)$, Chrysaora were 2.2 and $2.7(\mathrm{n}=2)$ and Aurelia $(\mathrm{n}=2)$ were 2.8 and 3.0. Leatherback $\mathrm{TP}_{\mathrm{CSIA}}$ from Seminoff et al.
Table 2. Estimated probabilities of relative prey contributions to the diets of leatherback turtles foraging in the California Current-Large Marine Ecosystem. Values were calculated using Bayesian inference in the R package 'SIMMR' (see Section 2 for details) and they represent the estimated proportions of each prey contribution. The frequencies for probability estimates are grouped into the following quantiles: 2.5, 25, 50 (median), 75, and $97.5 \%$

\begin{tabular}{|lccccc|}
\hline & $2.5 \%$ & $25 \%$ & $50 \%$ & $75 \%$ & $97.5 \%$ \\
\hline Aurelia & 0.01 & 0.03 & 0.05 & 0.08 & 0.17 \\
Chrysaora & 0.59 & 0.68 & 0.72 & 0.77 & 0.85 \\
Phacellophora & 0.01 & 0.02 & 0.03 & 0.05 & 0.10 \\
Thaliaceans & 0.06 & 0.13 & 0.18 & 0.22 & 0.31 \\
\hline
\end{tabular}

(2012) was $2.4(n=3$; Table 3). When we incorporated a turtle-specific TDF for those samples, the TP estimate for those leatherback samples was 3.1.

\section{DISCUSSION}

Examining feeding relationships in marine ecosystems can pose several challenges due to complex predator-prey interactions, cryptic life histories, and sampling difficulties associated with endangered and highly migratory species and/or fragile organisms. 
Table 3. Bulk stable isotope values, source $\left(\delta^{15} \mathrm{~N}_{\text {phe }}\right)$ and trophic $\left(\delta^{15} \mathrm{~N}_{\text {glu }}\right)$ amino acid values (\%o) with standard deviations in parentheses, and TP estimates using the Chikaraishi et al. (2009) approach. Leatherback values are from a previously published study, Seminoff et al. (2012). $\mathrm{TP}_{\text {bulk }}$ represents posterior TP estimates (median and 97.5\% credibility intervals) from bulk $\delta^{15} \mathrm{~N}$ values (see Supplement) using a Bayesian approach in the R package 'tRophicposition'

\begin{tabular}{|c|c|c|c|c|c|c|c|}
\hline Species & Sample & $\delta^{15} \mathrm{~N}$ & $\delta^{13} \mathrm{C}$ & $\delta^{15} \mathrm{~N}_{\mathrm{glu}}$ & $\delta^{15} \mathrm{~N}_{\text {phe }}$ & $\mathrm{TP}_{\mathrm{AA}}$ & $\mathrm{TP}_{\text {bulk }}$ \\
\hline Leatherback & $\begin{array}{l}1 \\
2 \\
3\end{array}$ & $\begin{array}{l}14.7 \\
15.9 \\
15.2\end{array}$ & $\begin{array}{l}-17.4 \\
-17.5 \\
-17.1\end{array}$ & $\begin{array}{l}21.3(0.6) \\
20.2(0.7) \\
21.4(0.3)\end{array}$ & $\begin{array}{l}7.4(0.4) \\
6.9(0.3) \\
7.5(0.4)\end{array}$ & $\begin{array}{l}2.4(0.2) \\
2.3(0.2) \\
2.4(0.2)\end{array}$ & $3.1(3.0-3.3)$ \\
\hline Aurelia & $\begin{array}{l}1 \\
2\end{array}$ & $\begin{array}{l}12.2 \\
12.1\end{array}$ & $\begin{array}{l}-16.6 \\
-17.3\end{array}$ & $\begin{array}{l}22.4(0.2) \\
22.9(0.1)\end{array}$ & $\begin{array}{l}5.3(0.7) \\
4.6(0.4)\end{array}$ & $\begin{array}{l}2.8(0.2) \\
3.0(0.2)\end{array}$ & $2.5(2.4-2.7)$ \\
\hline Chrysaora & $\begin{array}{l}1 \\
2\end{array}$ & $\begin{array}{l}10.1 \\
10.6\end{array}$ & $\begin{array}{l}-17.6 \\
-17.7\end{array}$ & $\begin{array}{l}20.3(0.6) \\
19.6(0.2)\end{array}$ & $\begin{array}{l}4.2(0.6) \\
7.2(0.7)\end{array}$ & $\begin{array}{l}2.7(0.2) \\
2.2(0.2)\end{array}$ & $2.3(2.2-2.4)$ \\
\hline Phacellophora & $\begin{array}{l}1 \\
2\end{array}$ & $\begin{array}{l}12.4 \\
12.6\end{array}$ & $\begin{array}{l}-16.9 \\
-16.1\end{array}$ & $\begin{array}{l}21.9(0.3) \\
24.0(0.5)\end{array}$ & $\begin{array}{l}4.1(0.4) \\
5.9(0.5)\end{array}$ & $\begin{array}{l}2.9(0.2) \\
2.9(0.2)\end{array}$ & $2.9(2.7-3.1)$ \\
\hline Thalicea & & & & & & & $1.9(1.8-2.0)$ \\
\hline
\end{tabular}

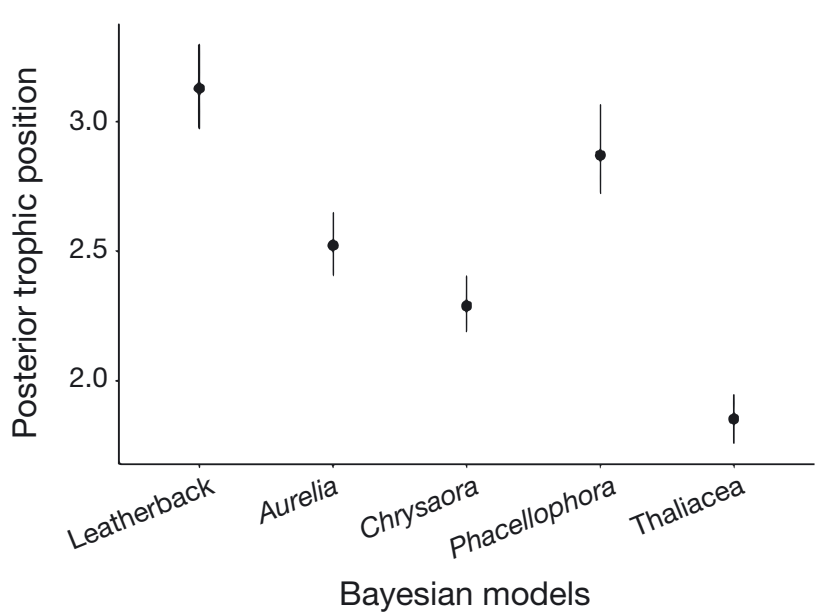

Fig. 5. Posterior trophic position $\left(\mathrm{TP}_{\text {bulk }}\right)$ estimates for leatherbacks and their gelatinous prey. $\mathrm{TP}_{\text {bulk }}$ values were calculated using bulk $\delta^{15} \mathrm{~N}$ values and a Bayesian framework in the R package 'tRophicposition'. Error bars represent Bayesian interference credible intervals around the $\mathrm{TP}_{\text {bulk }}$ estimates from Markov Chain Monte Carlo Simulations. See Section 2 and Eq. (1) for more detail

Our study examined the trophic relationships in an often-understudied component of marine food webs: gelatinous energy pathways that support higher-order consumers. Through stable isotope analyses and Bayesian statistical approaches, we provided insight into leatherback foraging ecology in the CC-LME, a highly productive ecosystem and critical foraging area for leatherback turtles Dermochelys coriacea originating from nesting beaches in the western Pacific.

\subsection{Trends in leatherback foraging ecology}

We focused on foraging leatherbacks, which provides a rare opportunity to gain information about male turtles, as they do not emerge from the water during the nesting season and thus are sampled less frequently than females (Dodge et al. 2011, Wallace et al. 2014). We found no differences in the $\delta^{15} \mathrm{~N}$ or $\delta^{13} \mathrm{C}$ values in skin between sexes, indicating that male and female leatherbacks exhibit similar habitat use and trophic patterns when foraging off California. This is similar to patterns observed in foraging leatherbacks at continental shelf sites along the northeastern coast of the United States (Dodge et al. 2011), as satellite telemetry data have indicated that that males and females also mix at temperate foraging grounds in the western North Atlantic (James et al. 2007). Our findings bolster the evidence of previous studies and provides promise for future isotopic research that aims to use female leatherbacks as a proxy for the larger adult population when sampling males is not possible.

We were particularly interested in using isotope values to examine leatherback foraging ecology over time in the CC-LME. Due to the logistical challenges associated with sampling leatherbacks in their foraging grounds, there are few studies with time series data (e.g. Wallace et al. 2014, Hetherington et al. 2018) on leatherback feeding ecology. We sampled leatherbacks in 7 summers over $13 \mathrm{yr}$ and recognize the limitations of our conclusions given the gaps in our sample collection. We found no long-term trend or changes in leatherback $\delta^{15} \mathrm{~N}$ values from 2003 to 2016, indicating that leatherback diet or TP did not shift during the years in which we sampled. We recognize that dietary shifts may have occurred over this time period during years for which we did not collect samples.

For $\delta^{13} \mathrm{C}$, which can reflect habitat use, we did not find a long-term trend. However, $\delta^{13} \mathrm{C}$ values were 
higher in 2005 compared with other years. Higher $\delta^{13} \mathrm{C}$ values at the base of the food web can be associated with nearshore systems compared with offshore, pelagic systems with lower $\delta^{13} \mathrm{C}$ values (Clementz \& Koch 2001). We hypothesize that leatherbacks exhibited altered foraging behavior in 2005. This hypothesis is corroborated by data from aerial surveys conducted the same year, which noted that leatherbacks exhibited a restricted range and were only encountered around San Francisco Bay (Peterson et al. 2006). In Monterey Bay, where leatherbacks have also been encountered but were not observed in 2005, Phacellophora and Aurelia were the dominant scyphozoan species, but around San Francisco Bay, Chrysaora fuscescens were densely aggregated in locations where leatherbacks were encountered (Peterson et al. 2006). Based on the isotope mixing model, leatherbacks in the CC-LME primarily forage on C. fuscescens, and to a lesser extent, thaliaceans (Fig. 4, Table 2). Therefore, our isotope data, coupled with aerial survey data support the hypothesis that leatherbacks selectively prey upon C. fuscescens, which may have been less abundant in certain leatherback foraging areas in 2005.

A previous study (Benson et al. 2007b) suggested that scyphozoan abundances are influenced by hydrographic features on the California coast, where upwelled water is retained in nearshore habitats (i.e. upwelling shadows; Graham \& Largier 1997), producing favorable conditions for gelatinous organisms that leatherbacks consume. In 2005, upwelling was delayed in portions of the CC-LME, and there were fewer wind relaxation events during the summer (Peterson et al. 2006). Upwelling strength around Monterey Bay was low in 2005 compared to other years (see Fig. S3 in the Supplement), which agrees with Peterson et al. (2006). It is possible that reduced or delayed upwelling may have impacted the abundance and distribution of large scyphozoans and therefore affected leatherback habitat use during 2005, where their range was more restricted to areas where C. fuscescens were still abundant (e.g. San Francisco Bay).

Interestingly, in 2005, salp and pyrosome abundances were higher than most other years in our time series (Fig. S4 in the Supplement). It is also possible that environmental conditions were less favorable for scyphozoans but favorable for filter-feeding thaliaceans, although we did not find a concurrent decrease in $\delta^{15} \mathrm{~N}$ values (i.e. diet switch to thaliaceans), and we lack a quantitative measure of scyphozoan abundance to test this hypothesis. Thaliacean abundances were similarly high in 2012, when a wide- spread salp bloom occurred in the southern CC-LME (Smith et al. 2014), which is also apparent in our thaliacean time series. Unfortunately, we could not directly compare leatherback foraging ecology between 2005 and 2012 because only one leatherback was sampled in 2012 .

Thaliacean abundance is of particular interest, as a recent report (Sutherland et al. 2018) suggests a range expansion of pyrosomes in the northeast Pacific Ocean, and our mixing model indicates that thaliaceans comprise $\sim 20 \%$ of leatherback diet. Future studies are needed to examine the ecological impacts of pyrosome blooms and range expansion in the CCLME, particularly as it relates to leatherbacks. If pyrosome density increases in leatherback foraging areas, pyrosomes may comprise an increasingly larger proportion of leatherback diet. However, future monitoring of leatherback trophic ecology is needed to test this hypothesis.

\subsection{Isotopic niches}

We were interested in resource use of both leatherbacks and gelatinous zooplankton, particularly as gelatinous taxa are understudied and recent studies illustrate their ecological importance in marine ecosystems (Henschke et al. 2016, Choy et al. 2017, Hays et al. 2018). We used the $\delta^{15} \mathrm{~N}$ and $\delta^{13} \mathrm{C}$ data to estimate the isotopic niches of leatherbacks and gelatinous zooplankton. Calculating standard ellipse areas can provide information about resource use and diet $\left(\delta^{15} \mathrm{~N}\right)$ as well as primary production and environment $\left(\delta^{13} \mathrm{C}\right.$ ) (Newsome et al. 2007, Rossman et al. 2016).

Bayesian estimates of isotopic niches (SEA-B) indicated that thaliaceans had a smaller niche area than leatherbacks, Chrysaora, and Phacellophora, but a larger niche than Aurelia. Overall, isotopic niches were comparable among species, particularly between leatherbacks, Chrysaora, and Phacellophora. A previous study found a $75 \%$ diet overlap between Chrysaora and Aurelia in the Northern California Current, where euphausiid eggs and nauplii and copepods comprised much of their diets, although Aurelia consumed fewer copepods and more pteropods and larvaceans than Chrysaora (Suchman $\&$ Brodeur 2005). Isotopic niche estimates suggest less overlap between Chrysaora and Phacellophora, and this discrepancy may be due to the spatial differences between our study and that of Suchman \& Brodeur (2005). Future studies that combine complementary metrics to evaluate niche width (i.e. gut con- 
tent analysis and stable isotope analysis) would be useful to further investigate our findings.

Of the gelatinous zooplankton, Phacellophora had the highest SEA-B, which may reflect its carnivorous and opportunistic feeding strategy. This supports previous work suggesting that Phacellophora are predators that consume copepods, fish larvae, and chaetognaths (Suchman \& Brodeur 2005); they also eat other scyphozoan medusae, including Aurelia and Chrysaora. Therefore, we would expect both higher TPs and isotopic niche widths for Phacellophora compared with other scyphozoans.

Leatherback SEA-B values were marginally higher than those of Phacellophora and Chrysaora and substantially higher than those of Aurelia and thaliaceans. We hypothesize that the high SEA-B values of leatherbacks reflect their ability to consume different types of gelatinous prey that span multiple trophic levels (e.g. salps and carnivorous scyphozoans). The larger isotopic niche may also be attributed to leatherbacks consuming commensal species (e.g. small crabs and fish) that are attached to scyphozoans. Although leatherbacks are unlikely to directly target these commensal species, they could comprise a small portion of leatherback diets and therefore contribute to their $\delta^{15} \mathrm{~N}$ and $\delta^{13} \mathrm{C}$ values.

Estimating SEA-B values may provide insights into isotopic niche widths of consumers (Newsome et al. 2007, Jackson et al. 2011); however, it is imperative to understand the potential confounding factors in these analyses that contribute to isotopic variability. For instance, stable isotope values are incorporated into consumer tissues over different time periods as protein turnover rates vary with tissue type (Seminoff et al. 2007, 2009). Isotopic variability may also reflect horizontal or vertical movement patterns of organisms (Hannides et al. 2009, Seminoff et al. 2012, Hetherington et al. 2018). For example, it is possible that higher SEA-B values in leatherbacks are attributed to their highly migratory behavior, where they integrate baseline $\delta^{15} \mathrm{~N}$ and $\delta^{13} \mathrm{C}$ values from multiple habitats. Future work that integrates isotopic niche widths with other approaches for estimating foraging ecology (e.g. animal-borne cameras, molecular techniques, and satellite telemetry data) would be useful for a comparison with patterns in SEA-B values. To evaluate offshore niches and habitat use, future studies should also sample leatherbacks when they arrive in neritic foraging grounds of the North Pacific. Sampling for this study occurred later (August to September), when the turtles had likely been present in neritic habitats for several months.

\subsection{Trophic structure}

We estimated TPs of leatherbacks and their gelatinous prey in the CC-LME using 2 methods, one that relied on bulk $\delta^{15} \mathrm{~N}$ values $\left(\mathrm{TP}_{\text {bulk }}\right)$ and one that used amino acid $\delta^{15} \mathrm{~N}$ values from CSIA-AA (TP $\left.\mathrm{TSIA}_{\mathrm{A}}\right)$, as these approaches have different advantages and limitations. Estimating TPs using $\delta^{15} \mathrm{~N}$ values requires a reliance on several parameters, including the trophic discrimination factor (TDF) and baseline $\delta^{15} \mathrm{~N}$ values, both of which can be variable and difficult to discern. Therefore, our objective was to estimate and compare TPs from 2 methods for a more robust understanding of trophic structure.

First, $\mathrm{TP}_{\text {bulk }}$ estimates were derived from a novel Bayesian approach (Quezada-Romegialli et al. 2018), which incorporates variability both in $\delta^{15} \mathrm{~N}$ values at the base of the food web and in the TDF and thus overcomes previous limitations of bulk isotope analysis. Furthermore, due to the low cost and labor associated with bulk isotope analysis, the sample size for $\mathrm{TP}_{\text {bulk }}$ is typically higher than for CSIA-AA. However, the Bayesian method still requires sampling of the base of the food web to estimate $\mathrm{TP}_{\text {bulk }}$, which is a major limitation of many bulk isotope studies.

We therefore used a second approach, $\mathrm{TP}_{\mathrm{CSIA}}$, which does not require sampling the base of the food web to account for baseline variability in $\delta^{15} \mathrm{~N}$ (Popp et al. 2007, McMahon \& McCarthy 2016). However, recent studies have highlighted the challenges of using CSIA-AA to determine TP. Most notably, amino acid TDFs can vary widely among taxa (Bradley et al. 2015, McMahon \& McCarthy 2016, Hetherington et al. 2017), which can introduce errors in TP estimates. Without controlled feeding experiments, it is often difficult to determine the TDFs of consumers.

Using the Bayesian approach, we found differentiation in median $\mathrm{TP}_{\text {bulk }}$ estimates among species, where leatherback $\mathrm{TP}_{\text {bulk }}$ was higher (3.1) than all potential prey, which is ecologically realistic considering that leatherbacks consume gelatinous zooplankton and should have higher TPs. $\mathrm{TP}_{\text {bulk }}$ estimates for thaliaceans were lower (1.8) compared to other taxa, which is what we anticipated for filter-feeding organisms. There was trophic overlap between Aurelia (median $\mathrm{TP}_{\text {bulk }}=2.5$ ) and Chrysaora (median $\mathrm{TP}_{\text {bulk }}=$ 2.3). Phacellophora TP estimates were slightly higher than other scyphozoans (median $\mathrm{TP}_{\text {bulk }}=2.9$ ) and closer to $\mathrm{TP}_{\text {bulk }}$ of leatherback turtles. These results support the hypothesis that Phacellophora are carnivorous predators and likely feed on a wide variety of prey items, including other scyphozoans and fish, 
and therefore may feed at a higher trophic level than Aurelia or Chrysaora.

We recognize the limitations of a small sample size for CSIA-AA and urge future studies to examine the robustness of these TP estimates with a larger sample size. The $\mathrm{TP}_{\mathrm{CSIA}}$ estimates for scyphozoans were in general agreement with those derived from bulk isotope analysis, where they ranged from 2.2 to 3.0. Phacellophora $\mathrm{TP}_{\mathrm{CSIA}}$ estimates were marginally higher than the other scyphozoans; however, $\mathrm{TP}_{\mathrm{CSIA}}$ generally indicated more trophic overlap among scyphozoans compared to our $\mathrm{TP}_{\text {bulk }}$ analyses. For Chrysaora, we found some intraspecific variation in $\mathrm{TP}_{\mathrm{CSIA}}$, where estimates were 2.2 and 2.7. These results are likely a relic of our very limited sample size $(n=2)$, which is unable to capture potential variability in intraspecies TP ranges. Alternatively, this result could indicate trophic flexibility, where Chrysaora feed on a mixture of lower and higher trophic level prey. Overall, our TP estimates of gelatinous zooplankton supported those from an ecosystem model of the Northern California Current (Field et al. 2006).

The leatherback CSIA-AA data were not analyzed for this study. Rather, the data were from nesting leatherbacks in the western Pacific that had migrated from the CC-LME (see Seminoff et al. 2012). We used these animals as a proxy for foraging leatherbacks, although the $\mathrm{TP}_{\mathrm{CSIA}}$ estimates may reflect foraging

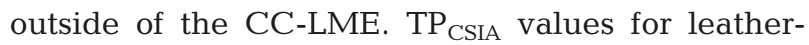
backs were lower $(\mathrm{Tp}=2.3-2.4)$ than expected, which Seminoff et al. (2012) attributed to the high TDF $(7.6 \%)$ that was used to estimate TP. More recent studies bolster this hypothesis and illustrate that TDFs vary among taxa, depending somewhat on their mode of nitrogen excretion (i.e. uric acid excretion) and trophic level (Germain et al. 2013, McMahon \& McCarthy 2016). Although there are no published amino acid TDFs for leatherbacks, one was derived for captive green turtles $5.03 \%$ from Lemons 2019). When we incorporated this lower TDF into the $\mathrm{TP}_{\text {CSIA }}$ equation for leatherbacks samples from Seminoff et al. (2012), estimates were more realistic (3.1-3.2) and in agreement with our $\mathrm{TP}_{\text {bulk }}$ estimates for leatherbacks.

The discrepancies between TP estimates highlight the benefit of using multiple complementary approaches to evaluating trophic structure, particularly when using isotope data from organisms with unknown bulk or amino acid TDFs. Our research highlights both the utility and caveats associated with isotope analyses and provides greater insight into the trophic structure of gelatinous energy pathways that support leatherbacks in the CC-LME.

\subsection{Conclusions}

Overall, the stable isotope data from our study provided a metric by which to evaluate energy pathways that support leatherbacks and examine temporal trends in leatherback foraging ecology in the CCLME. We found no difference in isotope values between male and female leatherbacks and no longterm shift in leatherback TPs over our sampling period from 2003 to 2016. An isotope mixing model suggests that leatherbacks selectively feed on Chrysaora fuscescens and thaliaceans. Anomalous upwelling conditions may affect leatherback habitat use and the abundances of gelatinous zooplankton in their foraging area, which would provide an explanation for differences in $\delta^{13} \mathrm{C}$ values in 2005 compared to other years.

Leatherback turtles continue to face an array of threats on both their nesting beaches (e.g. egg and female harvest and coastal development) and in their foraging habitats (e.g. harvest, fisheries interactions, plastic pollution, and contaminants). It is unclear how environmental shifts (e.g. a recent marine heatwave) and future climate change (e.g. increasing sea surface temperatures) may affect leatherback foraging dynamics, particularly through changes in prey distribution and availability. Because prey density is often a driver of predator habitat use, it is essential to identify resources and energy pathways that support populations of threatened species for a holistic approach to management. Our findings can be applied to models used to predict leatherback foraging ecology and habitat use in the CC-LME and how these parameters may change under future environmental conditions. Isotope values from gelatinous zooplankton and leatherback tissues can also be incorporated into ecosystem models, which will contribute to better understanding of the CC-LME food web.

Acknowledgements. We gratefully thank all captains, crew, and sea-going scientists and volunteers who assisted in field work to collect gelatinous zooplankton samples off Central California. We also thank Giulia Anderson, Karen Arthur, Brian Popp, and the University of Hawaii's Isotope Geochemistry Laboratory for assistance in sample preparation and isotope analyses. Lastly, we thank the 3 anonymous reviewers whose comments and suggestions improved the quality of the manuscript. Leatherback skin sampling was conducted under Endangered Species Act permit numbers 1227, 1596, and 15634, using animal handling protocols approved by the NOAA Southwest and Pacific Islands Regional Institutional Animal Care and Use Committee (Approval \# 011714) and in conformance with all applicable laws. Salp and pyrosome abundance data were obtained from Scripps Institution of Oceanography (SIO), where plankton sample 
analysis was supported by NSF grants to M.D. Ohman, SIO, and the SIO Pelagic Invertebrates Collection. Funding for this project was provided by the National Oceanic and Atmospheric Administration-Southwest Fisheries Science Center's Marine Mammal and Turtle Division.

\section{LITERATURE CITED}

Aleksa K (2017) Ecological and oceanographic influences on leatherback turtle behavior and scyphozoan jellyfish distributions in the Gulf of Mexico. PhD dissertation, University of Southern Mississippi, Hattiesburg, MI

Altabet MA (2001) Nitrogen isotopic evidence for micronutrient control of fractional $\mathrm{NO}_{3}{ }^{-}$utilization in the equatorial Pacific. Limnol Oceanogr 46:368-380

* Arthur KE, Kelez S, Larsen T, Choy CA, Popp BN (2014) Tracing the biosynthetic source of essential amino acids in marine turtles using $\delta^{13} \mathrm{C}$ fingerprints. Ecology 95: 1285-1293

Bailey H, Benson SR, Shillinger GL, Bograd SJ and others (2012) Identification of distinct movement patterns in Pacific leatherback turtle populations influenced by ocean conditions. Ecol Appl 22:735-747

Barnes C, Maxwell D, Reuman DC, Jennings S (2010) Global patterns in predator-prey size relationships reveal size dependency of trophic transfer efficiency. Ecology 91: 222-232

Baum JK, Worm B (2009) Cascading top-down effects of changing oceanic predator abundances. J Anim Ecol 78: 699-714

Benson SR, Dutton PH, Hitipeuw C, Samber B, Bakarbessy J, Parker D (2007a) Post-nesting migrations of leatherback turtles (Dermochelys coriacea) from JamursbaMedi, Bird's Head Peninsula, Indonesia. Chelonian Conserv Biol 6:150-154

Benson SR, Forney KA, Harvey JT, Carretta JV, Dutton PH (2007b) Abundance, distribution, and habitat of leatherback turtles (Dermochelys coriacea) off California, 19902003. Fish Bull 105:337-347

Benson SR, Eguchi T, Foley DG, Forney KA and others (2011) Large-scale movements and high-use areas of western Pacific leatherback turtles, Dermochelys coriacea. Ecosphere 2:art84

Bograd SJ, Lynn RJ (2003) Long-term variability in the southern California Current System. Deep Sea Res II 50: 2355-2370

* Bradley CJ, Wallsgrove NJ, Choy CA, Drazen JC, Hetherington ED, Hoen DK, Popp BN (2015) Trophic position estimates of marine teleosts using amino acid compound specific isotopic analysis. Limnol Oceanogr Methods 13: 476-493

Chikaraishi Y, Ogawa NO, Kashiyama Y, Takano Y and others (2009) Determination of aquatic food-web structure based on compound-specific nitrogen isotopic composition of amino acids. Limnol Oceanogr Methods 7:740-750

Choy CA, Haddock SHD, Robison BH (2017) Deep pelagic food web structure as revealed by in situ feeding observations. Proc Biol Sci 284:20172116

* Clementz MT, Koch PL (2001) Differentiating aquatic mammal habitat and foraging ecology with stable isotopes in tooth enamel. Oecologia 129:461-472

Cline JD, Kaplan IR (1975) Isotopic fractionation of dissolved nitrate during denitrification in the eastern tropical north Pacific Ocean. Mar Chem 3:271-299
Davidson AD, Boyer AG, Kim H, Pompa-Mansilla S and others (2012) Drivers and hotspots of extinction risk in marine mammals. Proc Natl Acad Sci USA 109:3395-3400

* DeNiro MJ, Epstein S (1981) Influence of diet on the distribution of nitrogen isotopes in animals. Geochim Cosmochim Acta 45:341-351

*Di Lorenzo E, Mantua N (2016) Multi-year persistence of the 2014/15 North Pacific marine heatwave. Nat Clim Chang 6:1042-1047

* Dodge KL, Logan JM, Lutcavage ME (2011) Foraging ecology of leatherback sea turtles in the Western North Atlantic determined through multi-tissue stable isotope analyses. Mar Biol 158:2813-2824

* Dodge KL, Galuardi B, Miller TJ, Lutcavage ME (2014) Leatherback turtle movements, dive behavior, and habitat characteristics in ecoregions of the Northwest Atlantic Ocean. PLOS ONE 9:e91726

* Dutton PH, Hitipeuw C, Zein M, Benson SR and others (2007) Status and genetic structure of nesting populations of leatherback turtles (Dermochelys coriacea) in the western Pacific. Chelonian Conserv Biol 6:47-53

*Estes JA, Duggins DO (1995) Sea otters and kelp forests in Alaska: generality and variation in a community ecological paradigm. Ecol Monogr 65:75-100

Field J, Francis R, Aydin K (2006) Top-down modeling and bottom-up dynamics: linking a fisheries-based ecosystem model with climate hypotheses in the Northern California Current. Prog Oceanogr 68:238-270

Fossette S, Hobson VJ, Girard C, Calmettes B, Gaspar P, Georges JY, Hays GC (2010) Spatio-temporal foraging patterns of a giant zooplanktivore, the leatherback turtle. J Mar Syst 81:225-234

FFossette S, Gleiss AC, Casey JP, Lewis AR, Hays GC (2012) Does prey size matter? Novel observations of feeding in the leatherback turtle (Dermochelys coriacea) allow a test of predator-prey size relationships. Biol Lett 8:351-354

Francis TB, Scheuerell MD, Brodeur RD, Levin PS, Ruzicka JJ, Tolimieri N, Peterson WT (2012) Climate shifts the interaction web of a marine plankton community. Glob Change Biol 18:2498-2508

Fry B (2006) Stable isotope ecology. Springer, New York, NY

* Germain LR, Koch PL, Harvey J, McCarthy MD (2013) Nitrogen isotope fractionation in amino acids from harbor seals: implications for compound-specific trophic position calculations. Mar Ecol Prog Ser 482:265-277

*Graham WM, Largier JL (1997) Upwelling shadows as nearshore retention sites: the example of northern Monterey Bay. Cont Shelf Res 17:509-532

Hannides CCS, Popp BN, Landry MR, Graham BS (2009) Quantification of zooplankton trophic position in the North Pacific Subtropical Gyre using stable nitrogen isotopes. Limnol Oceanogr 54:50-61

* Hannides CCS, Popp BN, Choy CA, Drazen JC (2013) Midwater zooplankton and suspended particle dynamics in the North Pacific Subtropical Gyre: a stable isotope perspective. Limnol Oceanogr 58:1931-1946

*Hays GC, Houghton JD, Myers AE (2004) Endangered species: pan-Atlantic leatherback turtle movements. Nature 429:522

* Hays GC, Doyle TK, Houghton JDR (2018) A paradigm shift in the trophic importance of jellyfish? Trends Ecol Evol 33:874-884

* Hazen EL, Jorgensen S, Rykaczewski RR, Bograd SJ and others (2013) Predicted habitat shifts of Pacific top predators in a changing climate. Nat Clim Chang 3:234-238 
Heaslip SG, Iverson SJ, Bowen WD, James MC (2012) Jellyfish support high energy intake of leatherback sea turtles (Dermochelys coriacea): video evidence from animalborne cameras. PLOS ONE 7:e33259

Henschke N, Everett JD, Richardson AJ, Suthers IM (2016) Rethinking the role of salps in the ocean. Trends Ecol Evol 31:720-733

Hetherington ED, Olson RJ, Drazen JC, Lennert-Cody CE, Ballance LT, Kaufmann RS, Popp BN (2017) Spatial foodweb structure in the eastern tropical Pacific Ocean based on compound-specific nitrogen isotope analysis of amino acids. Limnol Oceanogr 62:541-560

Hetherington ED, Seminoff JA, Dutton PH, Robison LC, Popp BN, Kurle CM (2018) Long-term trends in the foraging ecology and habitat use of an endangered species: an isotopic perspective. Oecologia 188:1273-1285

Hobson KA (1999) Tracing origins and migration of wildlife using stable isotopes: a review. Oecologia 120:314-326

Jackson AL, Inger R, Parnell AC, Bearhop S (2011) Comparing isotopic niche widths among and within communities: SIBER - Stable Isotope Bayesian Ellipses in R. J Anim Ecol 80:595-602

Jacox MG, Hazen EL, Zaba KD, Rudnick DL, Edwards CA, Moore AM, Bograd SJ (2016) Impacts of the 2015-2016 El Niño on the California Current System: early assessment and comparison to past events. Geophys Res Lett 43:7072-7080

James MC, Andrea Ottensmeyer C, Myers RA (2005) Identification of high-use habitat and threats to leatherback sea turtles in northern waters: new directions for conservation. Ecol Lett 8:195-201

James MC, Sherrill-Mix SA, Martin K, Myers RA (2006) Canadian waters provide critical foraging habitat for leatherback sea turtles. Biol Conserv 133:347-357

James MC, Sherrill-Mix SA, Myers RA (2007) Population characteristics and seasonal migrations of leatherback sea turtles at high latitudes. Mar Ecol Prog Ser 337: 245-254

Jones TT, Bostrom BL, Hastings MD, Van Houtan KS, Pauly D, Jones DR (2012) Resource requirements of the Pacific leatherback turtle population. PLOS ONE 7:e45447

Kurle CM, McWhorter JK (2017) Spatial and temporal variability within marine isoscapes: implications for interpreting stable isotope data from marine systems. Mar Ecol Prog Ser 568:31-45

Lemons G (2019) Amino acid stable nitrogen analysis and its application to ecological studies of the green sea turtle (Chelonia mydas). MS thesis, San Diego State University, San Diego, CA

Lorrain A, Graham BS, Popp BN, Allain V and others (2015) Nitrogen isotopic baselines and implications for estimating foraging habitat and trophic position of yellowfin tuna in the Indian and Pacific Oceans. Deep Sea Res II 113:188-198

Lynn RJ, Simpson JJ (1987) The California Current system: the seasonal variability of its physical characteristics. J Geophys Res Oceans 92:12947-12966

McCutchan JH Jr, Lewis WM Jr, Kendall C, McGrath CC (2003) Variation in trophic shift for stable isotope ratios of carbon, nitrogen, and sulfur. Oikos 102:378-390

McMahon KW, McCarthy MD (2016) Embracing variability in amino acid $\delta 15 \mathrm{~N}$ fractionation: mechanisms, implications, and applications for trophic ecology. Ecosphere 7: e01511

Montoya JP, Carpenter EJ, Capone DG (2002) Nitrogen fix- ation and nitrogen isotope abundances in zooplankton of the oligotrophic North Atlantic. Limnol Oceanogr 47: $1617-1628$

Myers RA, Worm B (2003) Rapid worldwide depletion of predatory fish communities. Nature 423:280-283

Newsome SD, Martinez del Rio C, Bearhop S, Phillips DL (2007) A niche for isotopic ecology. Front Ecol Environ 5: 429-436

Nielsen JM, Popp BN, Winder M (2015) Meta-analysis of amino acid stable nitrogen isotope ratios for estimating trophic position in marine organisms. Oecologia 178: 631-642

Ohkouchi N, Chikaraishi Y, Close HG, Fry B and others (2017) Advances in the application of amino acid nitrogen isotopic analysis in ecological and biogeochemical studies. Org Geochem 113:150-174

*Pace ML, Cole JJ, Carpenter SR, Kitchell JF (1999) Trophic cascades revealed in diverse ecosystems. Trends Ecol Evol 14:483-488

Paine RT (1980) Food webs: linkage, interaction strength and community infrastructure. J Anim Ecol 49:666-685

Parnell AC, Phillips DL, Bearhop S, Semmens BX and others (2013) Bayesian stable isotope mixing models. Environmetrics 24:387-399

* Pascual M, Neubert MG, Acuña JL, Solow AR and others (2016) Environmental drivers of salp Thalia democratica population dynamics from in situ observations. Mar Ecol Prog Ser 561:189-201

* Peavey LE, Popp BN, Pitman RL, Gaines SD, Arthur KE, Kelez S, Seminoff JA (2017) Opportunism on the high seas: foraging ecology of olive ridley turtles in the eastern Pacific Ocean. Front Mar Sci 4:348

Peterson B, Emmett R, Goericke R, Venrick E and others (2006) The state of the California current, 2005-2006: warm in the north, cool in the south. CCOFI Rep 47:30-74

Polis GA (1991) Complex trophic interactions in deserts: an empirical critique of food-web theory. Am Nat 138: 123-155

Polis GA, Strong DR (1996) Food web complexity and community dynamics. Am Nat 147:813-846

Popp BN, Graham BS, Olson RJ, Hannides CC and others (2007) Insight into the trophic ecology of yellowfin tuna, Thunnus albacares, from compound-specific nitrogen isotope analysis of proteinaceous amino acids. Terr Ecol 1:173-190

Post DM (2002) The long and short of food-chain length. Trends Ecol Evol 17:269-277

*Quezada-Romegialli C, Jackson AL, Hayden B, Kahilainen KK, Lopes C, Harrod C (2018) tRophicPosition, an R package for the Bayesian estimation of trophic position from consumer stable isotope ratios. Methods Ecol Evol 9:1592-1599

R Core Team (2016) R: a language and environment for statistical computing. R Foundation for Statistical Computing, Vienna. www.r-project.org

* Reich KJ, Bjorndal KA, Martínez del Rio C (2008) Effects of growth and tissue type on the kinetics of ${ }^{13} \mathrm{C}$ and ${ }^{15} \mathrm{~N}$ incorporation in a rapidly growing ectotherm. Oecologia 155:651-653

* Robinson NJ, Morreale SJ, Nel R, Paladino FV (2016) Coastal leatherback turtles reveal conservation hotspot. Sci Rep 6:37851

* Rossman S, Ostrom PH, Gordon F, Zipkin EF (2016) Beyond carbon and nitrogen: guidelines for estimating threedimensional isotopic niche space. Ecol Evol 6:2405-2413 
Ruzicka JJ, Brodeur RD, Emmett RL, Steele JH and others (2012) Interannual variability in the Northern California Current food web structure: changes in energy flow pathways and the role of forage fish, euphausiids, and jellyfish. Prog Oceanogr 102:19-41

Saba VS, Spotila JR, Chavez FP, Musick JA (2008) Bottomup and climatic forcing on the worldwide population of leatherback turtles. Ecology 89:1414-1427

Seminoff JA, Bjorndal KA, Bolten AB (2007) Stable carbon and nitrogen isotope discrimination and turnover in pond sliders Trachemys scripta: insights for trophic study of freshwater turtles. Copeia 2007:534-542

Seminoff JA, Jones TT, Eguchi T, Hastings M, Jones DR (2009) Stable carbon and nitrogen isotope discrimination in soft tissues of the leatherback turtle (Dermochelys coriacea): insights for trophic studies of marine turtles. J Exp Mar Biol Ecol 381:33-41

Seminoff JA, Benson SR, Arthur KE, Eguchi T, Dutton PH, Tapilatu RF, Popp BN (2012) Stable isotope tracking of endangered sea turtles: validation with satellite telemetry and $\delta^{15} \mathrm{~N}$ analysis of amino acids. PLOS ONE 7:e37403

Sibert J, Hampton J, Kleiber P, Maunder M (2006) Biomass, size, and trophic status of top predators in the Pacific Ocean. Science 314:1773-1776

Smith K Jr, Sherman A, Huffard C, McGill P and others (2014) Large salp bloom export from the upper ocean and benthic community response in the abyssal northeast Pacific: day to week resolution. Limnol Oceanogr 59: 745-757

Starbird CH, Baldridge A, Harvey JT (1993) Seasonal occurrence of leatherback sea turtles (Dermochelys coriacea)

Editorial responsibility: Keith Hobson,

London, Ontario, Canada in the Monterey Bay region, with notes on other sea turtles. Calif Fish Game 79:54-62

* Suchman CL, Brodeur RD (2005) Abundance and distribution of large medusae in surface waters of the northern California Current. Deep Sea Res II 52:51-72

* Sutherland KR, Sorensen HL, Blondheim ON, Brodeur RD, Galloway AWE (2018) Range expansion of tropical pyrosomes in the northeast Pacific Ocean. Ecology 99: 2397-2399

*Vander Zanden HB, Arthur KE, Bolten AB, Popp BN and others (2013) Trophic ecology of a green turtle breeding population. Mar Ecol Prog Ser 476:237-249

Voss M, Dippner JW, Montoya JP (2001) Nitrogen isotope patterns in the oxygen-deficient waters of the Eastern Tropical North Pacific Ocean. Deep Sea Res I 48: 1905-1921

* Wallace BP, Saba VS (2009) Environmental and anthropogenic impacts on intra-specific variation in leatherback turtles: opportunities for targeted research and conservation. Endang Species Res 7:11-21

*Wallace BP, Seminoff JA, Kilham SS, Spotila JR, Dutton PH (2006) Leatherback turtles as oceanographic indicators: stable isotope analyses reveal a trophic dichotomy between ocean basins. Mar Biol 149:953-960

Wallace BP, DiMatteo AD, Bolten AB, Chaloupka MY and others (2011) Global conservation priorities for marine turtles. PLOS ONE 6:e24510

Wallace BP, Schumacher J, Seminoff JA, James MC (2014) Biological and environmental influences on the trophic ecology of leatherback turtles in the northwest Atlantic Ocean. Mar Biol 161:1711-1724

Submitted: February 4, 2019; Accepted: August 23, 2019 Proofs received from author(s): December 3, 2019 